УДК 338.48-44(1-22)

\title{
ОСОБЛИВОСТІ РОЗВИТКУ СІЛЬСЬКОГО ЗЕЛЕНОГО ТУРИЗМУ НА ВІННИЧЧИНІ
}

\section{FEATURES OF RURAL DEVELOPMENT GREEN TOURISM IN VINNITSA REGION}

\author{
Табенська Оксана Ігорівна \\ кандидат економічних наук, старший викладач, \\ Вінницький національний аграрний університет \\ ORCID: https://orcid.org/0000-0001-9629-9366
}

Tabenska Oksana

Vinnytsia National Agrarian University

\begin{abstract}
Досліджено сучасні глобальні проблеми людства, попит на природні ресурси, ефективний розвиток сільських територій, напрями підвищення конкурентоспроможності вітчизняного сільського туризму, переваги створення інноваційної кластерної моделі для розвитку регіонів. Визначено, що об'єднання у кластерні мережі дозволяє використати інноваційний потенціал регіону, удосконалити якість надання туристичних послуг. Проаналізовано переваги створення «Еко-центру у Стіні» в селі Стіна Вінницької області. Запропоновано проєктну модель взаємовідносин у туристично-рекреаційному кластері «Вінниччина», особлива увага звертається на організацію відпочинку в домашніх умовах у сільській місцевості, виготовлення екологічної продукції та розвиток ремесел. У статті розглянуті проблеми та перспективи розвитку сільського зеленого туризму, види туристичних маршрутів, туристичні стежки, культура, звичаї та обряди.
\end{abstract}

Ключові слова: глобальні проблеми людства, туризм, сільський зелений туризм, інноваційна кластерна модель, засоби розміщення туристів, синергійний ефрект.

Исследованы современные глобальные проблемы человечества, спрос на природные ресурсы, эфрфрективное развитие сельских территорий, направления повышения конкурентоспособности отечественного сельского туризма, преимущества создания инновационной кластерной модели для развития регионов. Определено, что объединение в кластерные сети позволяет использовать инновационный потенциал региона, усовершенствовать качество предоставления туристических услуг. Проанализированы преимущества создания «Эко-центра в Стене» в селе Стена Винницкой области. Предложена проектная модель взаимоотношений в туристско-рекреационном кластере «Винниччина», особое внимание обращается на организацию отдыха в домашних условиях в сельской местности, изготовление экологической продукции и развитие ремесел. В статье рассмотрены проблемы и перспективы развития сельского зеленого туризма, виды туристических маршрутов, туристические тропы, культура, обычаи и обряды.

Ключевые слова: глобальные проблемы человечества, туризм, сельский зеленый туризм, инновационная кластерная модель, средства размещения туристов, синергитический эфорект.

In the context of globalization of economic life for the economy in the country remains relevant issue of manufacturing competitive products that meet international quality standards and ensure the economic security of the state. What are the prospects for agricultural production? Who should dominate it: a family farm that preserves the rural population and its historical traditions, or industrialized agricultural giants? The article considers ways of increasing the competitiveness of domestic rural tourism. Investigated advantages of the innovation cluster model for regional development based on a synergistic effect. At this stage for Ukraine, in general and Vinnitsa region, in particular, is very relevant research and implementation of innovative strategies to ensure effective development of tourism industry. Foreign experience shows that government support rural development, infrastructure, information, logistics systems. Special attention also deserves issue of certification and categorization. One of the important reasons for the study of foreign and domestic experience and create integrated organizations is to reduce transaction costs (advertising products, negotiation). Summarizes the problems that were highlighted at the national forum on rural / green tourism in the framework of the project of the NGO "development Center pangeya Ultima" with the support of the Embassy of Finland in Ukraine. The forum began effective cooperation of the Ministry of agrarian policy and food, the Department of tourism and resorts of Ministry of economic development and trade, local authorities, a significant number of scientific 
research institutions, educational institutions, tour operators, catering establishments. The advantages of creating an "Eco-center in the Wall" in the village of Wall of Vinnytsia region are analyzed. A project model of relations in the tourist and recreational cluster "Vinnytsia" is proposed, special attention is paid to the organization of recreation at home in rural areas, the manufacture of environmental products and the development of crafts.

Keywords: global problems of mankind, tourism, rural green tourism, innovative cluster model, means of accommodation of tourists, synergistic effect.

Постановка проблеми. Територія України досить різноманітна і задовольняє потреби у відпочинку, відновленні фрізичних та духовних сил, не лише місцевих мешканців, а й іноземних туристів. У зв'язку з негативними тенденціями у розвитку міжнародного туризму, а також пандемією, виникає необхідність ефективного розвитку внутрішнього туризму. Коронавірусне захворювання (COVID-19) - це інфеекційна хвороба, яку спричиняє новий штам коронавірусу. Ризики, які виникли на сьогоднішній день, спричиняють потужні конорліктні та стресові ситуації. Саме за допомогою сприятливої позитивної атмосорери «хюге», яка створена в агросадибах, пансіонатах, апартаментах відбувається відновлення фрізичного та психологічного здоров'я населення.

Аналіз досліджень і публікацій. Підвищення конкурентоспроможності вітчизняного сільського туризму, інноваційні стратегії розвитку організації, проблеми та перспективи розвитку сільського туризму, ідентичність націй, напрями розвитку екологоорієнтованого агровиробництва у країнах Європейського Союзу, переваги створення туристичних кластерів, теоретичні аспекти диверсифрікації сільськогосподарської діяльності підприємств АПК, державну підтримку підприємництва: світовий досвід, традиційні символи і магічні ритуали українців, розвиток сільського туризму через створення туристичних кластерів досліджували провідні вчені та працівники галузі, зокрема: Гібернау М. [1], Вікінг М. [2], Бігдан О.В. [3], Перегуда Є.Ф. [4], Ходан І.В. [5], Петрук В.Г. [6], Босий О. [7], Дармостук Д.Г. [11].

Виділення невирішених раніше частин загальної проблеми. Варто зауважити, що потребує подальших досліджень недосконалість законодавчої бази для сільського зеленого туризму; координація сільського зеленого туризму на рівні області, району; профресійна освіта господарів агроосель та персоналу; пільгове кредитування та надання субсидій; а також преференцій для осіб, які створюють сприятливі умови для розвитку сільського зеленого туризму, в яких налічується менше 10-ти ліжко-місць, а також удосконалення діяльності професійних громадських об'єднань.
Кластерний підхід у сорері туризму активізує підприємництво через концентрацію ділової активності, тому сприяє створенню робочих місць, доходів, поліпшенню якості туристичних послуг, життя населення на території його запровадження. Досягається це завдяки зростанню конкурентоспроможності, можливості інтеграції інтелектуальних, природно-рекреаційних, трудових, орінансових матеріальних ресурсів у забезпеченні якості виробництва та послуг, що надаються.

Формулювання цілей статті (постановка завдання). Провести дослідження конкурентоспроможності вітчизняного сільського туризму на основі інноваційних стратегій розвитку. Проаналізувати переваги створення «Еко-центру у Стіні» в селі Стіна Вінницької області. Створити проєктну модель взаємовідносин у туристично-рекреаційному кластері «Вінниччина», необхідно звернути увагу на організацію відпочинку в домашніх умовах у сільській місцевості, виготовлення екологічної продукції та розвиток ремесел.

Виклад основного матеріалу дослідження. Наші будинки, села і міста розміщені на території країни. Крім того, територія традиційно була головним джерелом живлення для людей і навіть сьогодні продукти й природні ресурси країни мають велике значення і становлять вирішальний компонент багатства нації. А перетворена на краєвид, територія набуває зовсім іншого значення для тих, хто належить до неї, тих, хто здатний вирізняти конкретні місця, де відбувалися пам'ятні битви та події, і визначати конкретні пам'ятки і святині, які конституюють окремий характер нації.

Люди зрештою дійшли думки, що краєвид утілює традиції, історії та культуру нації, яку вони поділяють разом із предками. Краєвид це ще й джерело краси, піднесення та експлуатації. Він перетворився на символ нації, що втілює традиції, ідеї, сподівання і почуття, окремі 3 яких пробуджують сильне чуття належності до нації [1, с. 33-36].

Одна 3 причин високого рівня щастя в Данії - вдала збалансованість життя і праці, що дає людям змогу мати час на сім'ю та друзів. За Показником кращого життя, запропонованим Організацією економічного спів- 
робітництва й розвитку (ОЕСР), данці мають більше вільного часу, ніж мешканці решти країн - членів (ОЕСР), і згідно з Європейським соціальним анкетуванням 33 відсотки данців стверджують, що почуваються здебільшого спокійно і мирно, тоді як у Німеччині так можуть зазначити лише 23 відсотки населення, у Франції - 15, а у Великій Британії 14 відсотків [2, с. 274-278].

Стрімкий ріст населення в останні десятиліття зумовив зростання попиту на продукти харчування, що призводить до збільшення негативного впливу на навколишнє середовище. Враховуючи зазначені фрактори, побудова і практична реалізація належної до сорормованих умов державної політики екологізації агровиробництва $є$ одним із пріоритетних завдань сьогодення.

Так, з метою захисту, збереження і поліпшення якості води, повітря, ґрунту та біорізноманіття значні зусилля країн Європейського Союзу (далі - ЄС) спрямовані на інтеграцію екологічних аспектів у Спільній сільськогосподарській політиці (САП). Реалізується (САП) через визначення ряду стратегічних орієнтирів, на яких в подальшому ґрунтуються Наці- ональні стратегічні плани країн-членів $€ C$. Список зазначених орієнтирів складається із шести ключових компонентів (рис. 1).

Політика екологізації сільського господарства може мати різне значення та наслідки у короткостроковій та довгостроковій перспективах. Здійснення природоохоронної діяльності на перших етапах призводить до скорочення обсягів виробництва продукції. Однак у довгостроковій перспективі вона дає можливість забезпечити екологічну стійкість сільських територій та виробництва (у тому числі уникнути виснаження ресурсів), економічне зростання галузі та соціальний добробут сільського населення [3, с. 23-27].

Важливим $€$ вивчення й застосування досвіду аграрної підприємницької діяльності Європейського Союзу (ЄС). Нині в системі оцінок розвитку аграрної підприємницької діяльності $€ C$ розроблені типи диверсифрікації господарської діяльності, до яких належить сільський туризм, переробка сільськогосподарської продукції, обробка деревини, біоенергетика тощо.

Під дану типологію може підпадати також диверсифрікаційна діяльність українських

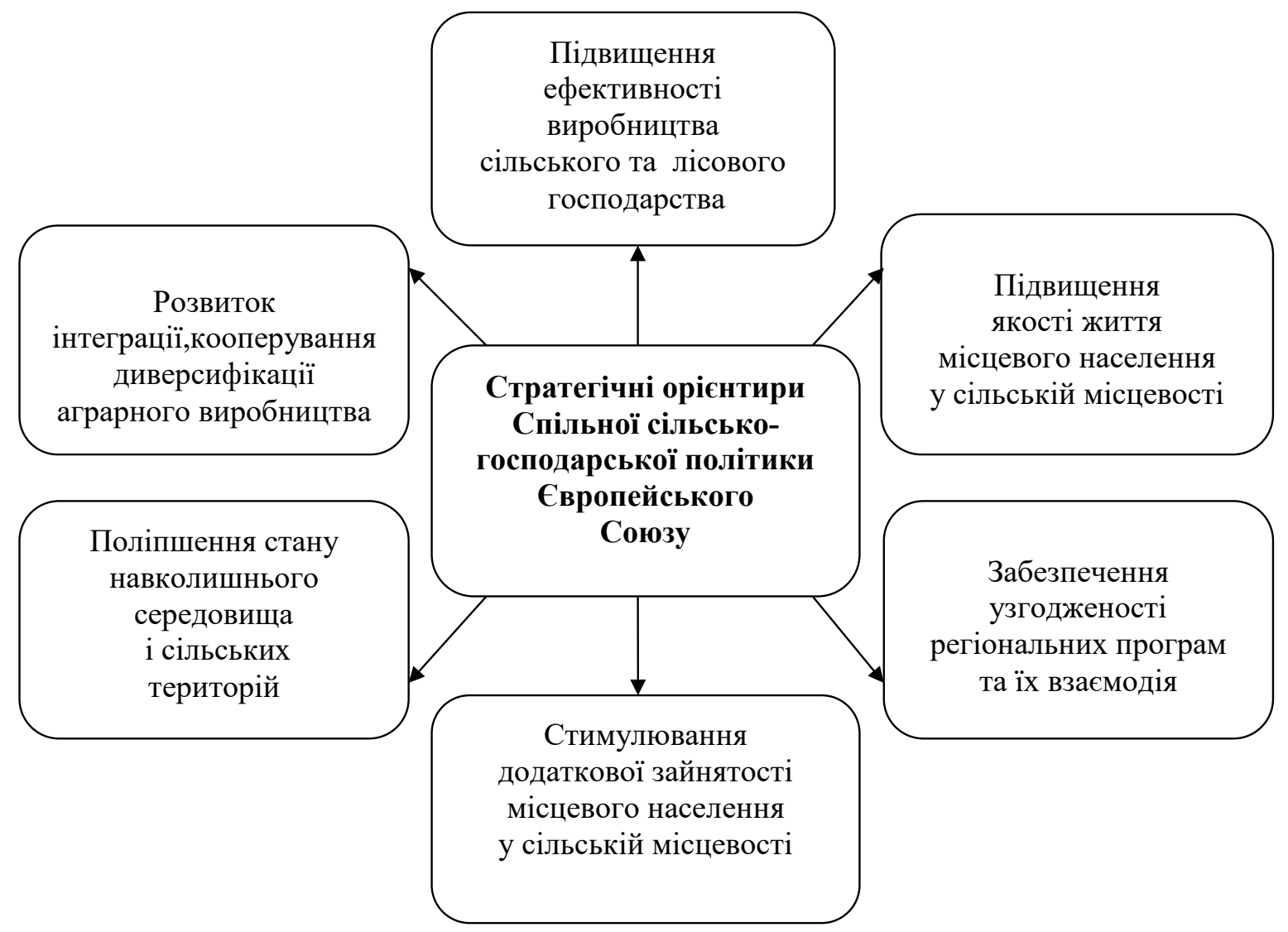

Рис. 1. Стратегічні орієнтири Спільної сільськогосподарської політики Європейського Союзу

Джерело: [3, с. 23-27] 
аграрників. Виявлено, що економічно доцільно проводити диверсифрікаційну стратегію в сільськогосподарських підприємствах, оскільки це дає змогу оперативніше використовувати вільні ресурси, реагувати на кон'юктуру ринків і значно знижувати рівень ризиків, які виникають в господарської діяльності [4, с. 113-116].

Для України найбільш оптимальними шляхами державної підтримки підприємництва є: стратегічний план розвитку малого підприємництва та звіт про результати його виконання; мікрокредитування та участь банку у фрінансуванні проектів інвестиційного характеру; виготовлення екологічно чистої продукції в аграрному секторі; підтримка інноваційного підприємництва для посилення конкурентоспроможності країни; створення сприятливого інвестиційного клімату [5, с. 36-42].

Екотуризм це єдиний напрямок в індустрії туризму, який зацікавлений у збереженні свого головного ресурсу - природного середовища або його окремих компонентів (пам'яток природи, певних видів тварин чи рослин і т.д.). Отже, відмінні риси екотуризму полягають у тому, що він створює і задовольняє бажання людини спілкуватися з природою, запобігає негативний вплив на екологію, культуру, естетику, і змушує туристичний потенціал служити на благо природи і соціально-економічного розвитку [6, с. 8-9].

Вітчизняний вчений-етнограф Босий О. в своїх дослідженнях зазначає, що: ритуал і символ виконують ряд життєво важливих функцій у культурі: вони виступають активним регулятором соціальної поведінки людини, інструментом її адаптації в етнокультурні, центрують ідейно-цінністні орієнтації. Роль символів як дієвого стабілізаційного інструмента культури особливо посилюється в періоди кардинальних соціальних змін та екологічних криз. Адже саме через символи носії традиції моделюють світ, і таким чином підпорядковують його собі [7].

Важливою для дослідження розвитку сільського зеленого туризму є діяльність Громадських організацій «Наше Поділля» та Центру розвитку «Пангея Ультіма», які досить успішно фрункціонують у місті Вінниці. Необхідно зазначити, що «Image Mapping» це проєкт 3 побудови міжкультурного діалогу, оновлення та зображення краси сільських громад. Він сприяє міжнародному міжособистому обміну на селі, розвиває неформальне навчання, активує населення під час акцій в громадах, досліджує місцевий культурний спадок та популяризує його для збільшення ймовірності в"їзного сільського туризму.
У березні 2017 року відбулася важлива подія для жителів села Стіна Томашпільського району Вінницької області, в межах інноваційного проєкту за підтримки Корпусу Миру США був відкритий «Еко-центр у Стіні» співробітниками, волонтерами Громадських організацій «Наше Поділля» та Центру розвитку «Пангея Ультіма».

Мешканці села Стіна пропонують туристам: екскурсію «Історичними стежками Стіни»; ознайомлення 3 «Живою картиною»; 3 культурним надбанням українців у Краєзнавчому музеї; з особливостями діяльності, місією «Еко-центра у Стіні»; відвідати штольні та досліджувати лікарські рослини на луках та вздовж річки [8, с. 1-6].

Необхідно зазначити, що Комплекс Миколаївської церкви разом зі старовинним кладовищем також знаходиться у селі Стіна Вінницької області. Розташований він на Замковій горі, яка нагадує стіну або вал. Поселення у цій місцевості називалося Стіною через те, що стрімкі схили річкової долини в околицях міста нагадували круті стіни.

Варто зазначити, що 12 кілометрів вздовж річки Русава, гірські краєвиди, ліси та багато різної рослинності - саме такою виглядає Стіна, яку ще називають «Маленькими Карпатами». На околиці $€$ заповідник місцевого значення «Сонна поляна», де щороку навесні розквітає рідкісна рослина сон-трава. Також дана місцевість $€$ відомим центром вишивання на східному Поділлі. Чорний та червоний колір займали особливе місце у стінянській вишивці. Протягом тривалого періоду значна кількість місцевих мешканців виготовляли яскраві килими. Місцева громада підтримала пропозиції волонтерів і створила власну марку «VERETA» [9, с. 1-6].

Основою життєдіяльності будь-якого суспільства $\epsilon$ безпечне природне навколишнє середовище, що залишається не лише запорукою добробуту та якості життя, але й гарантією подальшого розвитку людської цивілізації.

Поступове усвідомлення людством нових загроз (високий ступінь зосередженості шкідливих виробництв; високий рівень ресурсота енергоспоживання; відсутність сучасних екологічних технологій; повільна, але неминуча деградація генофронду населення примушують суспільство шукати нові підходи до соціально-економічного розвитку регіонів та природокористування [10, с. 192-201].

Тож, створення кластерів у сорері сільського зеленого туризму $\epsilon$ одним із найважливіших методів інноваційного розвитку 


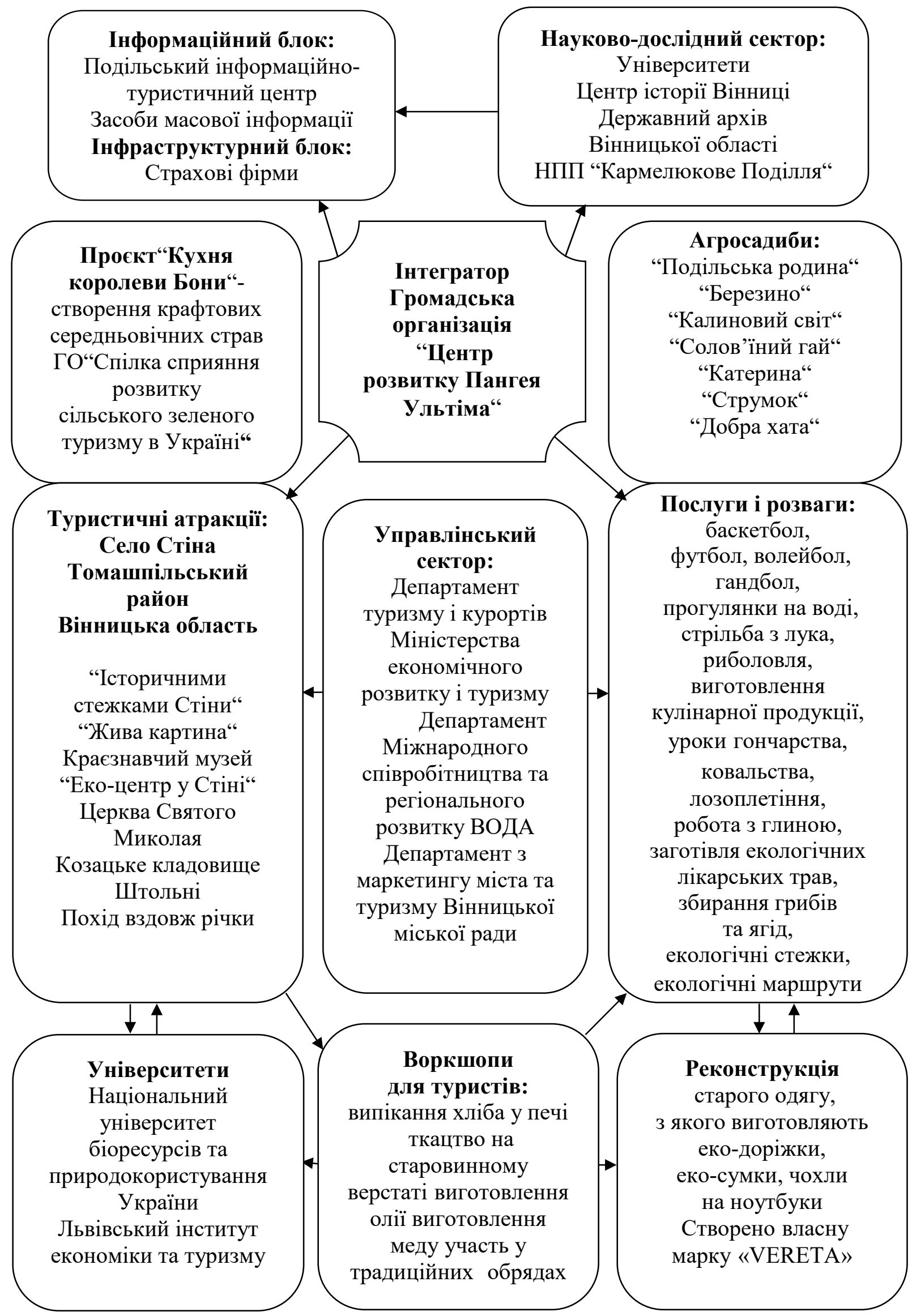

Рис. 2. Проєктна модель взаємовідносин в туристично-рекреаційному кластері «Вінниччина» Джерело: розроблено автором 
туристичної галузі, методом об'єднання традиційних і нових фрорм організації сільського зеленого туризму та методом раціонального використання природного потенціалу регіону.

Проєктна модель взаємовідносин у туристично-рекреаційному кластері «Вінниччина» відображена на (рис. 2).

Кластер сільського зеленого туризму можна визначити, як сконцентровану на певній території групу взаємопов'язанихпідприємств, установ та організацій сорери туризму та гостинності (туроператори, туристичні агенти, засоби розміщення, харчування) та інших пов'язаних із нею галузей (транспорту і зв'язку, торгівлі та ін.), місцевих органів влади та громадських об'єднань, що взаємодіють [11, с. 1-6].

Висновки. Отже, за допомогою кластерної фрорми організації підприємства можна удосконалити механізм управління, спеціалізацію, кооперацію, раціонально використовувати територіальний поділ та ресурси.

Також кластерний механізм покращує рівень життя населення, підвищує конкурентоспроможність бізнесу, розташованого на певній території, підтримує ефективний бізнес-клімат та забезпечує перехід до комплексного використання потенціалу всієї держави.

Регіон має також значні туристично-рекреаційні можливості, використання яких може бути покращено шляхом фрормування кластерів сільського зеленого туризму, виробництва народних промислів.

Необхідно продовжувати дослідження переваг створення інноваційної кластерної моделі для розвитку регіонів на основі синергійного ефекту.

\section{СПИСОК ВИКОРИСТАНИХ ДЖЕРЕЛ:}

1. Гібернау М. Ідентичність націй. Київ : Темпора, 2012. 304 с.

2. Вікінг М. Маленька книга хюге. Як жити добре по-данськи. Харків : Клуб сімейного дозвілля, 2017.288 с.

3. Бігдан О.В. Напрями розвитку екологоорієнтованого агровиробництва у країнах Європейського Союзу. Агросвіт. 2013. № 4. С. 23-27.

4. Перегуда Є.Ф. Теоретичні аспекти диверсисрікації сільськогосподарської діяльності підприємств АПк. Економіка АПК. 2013. № 10. С. 113-116.

5. Ходан І.В. Державна підтримка підприємництва: світовий досвід загального та особливого. Формування ринкових відносин в Україні. 2011. № 8(123). С. 36-42.

6. Петрук В.Г. Екогеографрія та екотуризм : Навчальний посібник. Вінниця : ТОВ «Нілан-ЛТД», 2016. 178 с.

7. Босий О. Священе ремесло. Традиційні символи і магічні ритуали українців. Вінниця: «Діло» ФОП Рогальська І.О., 2004. 220 с.

8. Проєкт «Image Mapping» Громадського об'єднання «Центр розвитку Пангея Ультіма». URL: http://www.pangeya.com.ua/index.php/ouractivities/ethno-tourism/208-im2015.html (дата звернення: 20.01.2021).

9. Однорог М. «Маленькі Карпати» з каменю і легенд: історія села Стіна. URL: https://vezha.ua/malenkikarpaty-z-kamenyu-i-legend-istoriya-sela-stina-fotoreportazh (дата звернення: 20.01.2021).

10. Паулі Г. Синя економіка. 10 років, 100 інновацій, 100 мільйонів робочих місць. Доповідь Римського клубу. Київ : "Risk Reduction Foundation", 2012. 320 с.

11. Дармостук Д.Г. Розвиток сільського туризму через створення туристичних кластерів. Теорія та практика державного управління. 2016. № 4(55). С. 1-6.

\section{REFERENCES:}

1. Hibernau M. (2012) Identychnist natsii [Identity of nations]. Kyiv: Tempora, 304 p. (in Ukrainian)

2. Vikinh M. (2017) The Little Book of Hugo. How to Live Well in Danish [Hugh's little book. How to live well in Danish]. Kharkiv: Family Leisure Club, $288 \mathrm{p}$.

3. Bihdan O.V. (2013) Napriamy rozvytku ekolohooriientovanoho ahrovyrobnytstva u krainakh Yevropeiskoho Soiuzu [Directions of development of ecologically oriented agricultural production in the countries of the European Union]. Ahrosvit, no. 4, pp. 23-27.

4. Perehuda Ye.F. (2013) Teoretychni aspekty dyversyfikatsii silskohospodarskoi diialnosti pidpryiemstv APK. Theoretical aspects of diversification of agricultural activities of agricultural enterprises]. Ekonomika APK, no. 10, pp. 113-116.

5. Khodan I.V. (2011) Derzhavna pidtrymka pidpryiemnytstva: svitovyi dosvid zahalnoho ta osoblyvoho [State support of entrepreneurship: world experience of general and special]. Formuvannia rynkovykh vidnosyn v Ukraini, no. 8 , pp. $36-42$.

6. Petruk V.H. (2016) Ekoheohrafiia ta ekoturyzm [Ecogeography and ecotourism]: Navchalnyi posibnyk. Vinnytsia, 178 p. (in Ukrainian) 
7. Bosyi O. (2004) Sviashchene remeslo. Tradytsiini symvoly i mahichni rytualy ukraintsiv. ekoturyzm [Sacred craft]. Traditional symbols and magical rituals of Ukrainians. Vinnytsia, 220 p. (in Ukrainian)

8. Proiekt «Image Mapping» Hromadskoho obiednannia «Tsentr rozvytku Panheia Ultima» (2020) [Image Mapping Project of the Pangea Ultima Development CenterNGO]. Avaiable at: http://www. pangeya.com.ua/ index.php/ ouractivities/ethno-tourism/208-im2015.html (accessed 20 January 2021).

9. Odnoroh M. (2018) «Malenki Karpaty» $z$ kameniu i lehend: istoriia sela Stina ["Little Carpathians" of stone and legends: the history of the village of Wall]. Avaiable at: https://vezha.ua/malenki-karpaty-z-kamenyu-i-legend-istoriya-sela-stina-fotoreportazh (accessed 20 January 2021).

10. Pauli H. (2012) Synia ekonomika. 10 rokiv, 100 innovatsii, 100 milioniv robochykh mists [Blue economy. 10 years, 100 innovations, 100 million jobs]. Dopovid Rymskoho klubu. Kyiv: Risk Reduction Foundation, 320 p. (in Ukrainian)

11. Darmostuk D.H. (2016) Rozvytok silskoho turyzmu cherez stvorennia turystychnykh klasteriv [Development of rural tourism through the creation of tourist]. Teoriia ta praktyka derzhavnoho upravlinnia, no. 4(55), pp. 1-6. 